\title{
Android Based Smart Door Locking System
}

\author{
Adarsh V Patil \\ Dept. of Electronics and Communication \\ VVCE, Mysuru, Karnataka, India
}

\author{
Akshay S \\ Dept. of Electronics and Communication \\ VVCE, Mysuru, Karnataka, India \\ CHandanB Patgar \\ Dept. of Electronics and Communication \\ VVCE, Mysuru, Karnataka, India
}

\author{
Sreevarsha Prakash \\ Dept. of Electronics and Communication \\ VVCE, Mysuru, Karnataka, India \\ Mahadevaswamy \\ Dept. of Electronics and Communication \\ VVCE, Mysuru, Karnataka, India \\ Sharath Kumar A J \\ Dept. of Electronics and Communication \\ VVCE, Mysuru, Karnataka, India
}

\begin{abstract}
With the advancement in technology Smart door locking system have become more advanced. The android based smart door lock system here is basically designed for normal mode and multi mode operations. Such system is very much required in Bank and Business organization. The system also gives functionalities for general user, where single user is authorized to operate the lock. The cost effective implementation with advanced functionality and easy to use interface makes the system very useful.
\end{abstract}

Keywords: Arduino Uno, Android, Smart Phone.

\section{INTRODUCTION}

Android Based Smart door locking system is designed to prevent unauthorized access, trespassing and intrusion. Banks, corporate offices, financial organization, jewellery shops, and government organization are some of the common targets where unauthorized access, trespassing and intrusion take place. Normally the aim behind such activities isstealing money, jewels or any important documents for individual gain. The purpose of Android Based Smart door locking system is to provide a smart solution to overcome these challenges and provide a feasible solution.

This system works on pre- decided password concept. It increases the security level to prevent an unauthorized unlocking done by attacker. In case the user forgets the passwords, system gives the flexibility to the user to change or reset the password. This automatic password based lock system gives user more secure way of locking-unlocking the system.

\section{LITERATURE REVIEW}

Many automated advanced door locking system has been developed and it's popularly used in many places like commercial buildings and organization. Some of these automated doors locking system are based on RFID (Radiofrequency identification).

- The RFID card reader detects and checks the user accessibility. When the card is brought near the reader, it identifies the radio frequency of the card and thus verifies the keybut these systems are very expensive. Various control systems are being designed over the years to prevent unauthorized access. The main aim for providing locks for our home, school, office, and building is for security of our lives and property. It is therefore important to have convenient way of achieving this. Lia Kamelia, Alfin Noorhassan S.R, MadaSanjaya and W.S., Edi Mulyana has implemented a "Door - Automation System Using Bluetooth", the implementation was on Android platform. So the implementation cost is less and affordable by a common user. With the use of wireless Bluetooth connection the system installation in more easy way [3]. Shilpi Banerjee has implemented an "Automatic Password Based Door Lock System". This system works on pre- decided password concept. It increases the security level to prevent an unauthorized access done by the attacker. In case the user forgets the passwords, certain privalages are given to the user to change or reset the password. This automatic password based lock system gives user more secure way of lockingunlocking the system [5]. Arpita Mishra, Siddharth Sharma, Sachin Dubey, S. K. Dubey has implemented a "Password Based Security Lock Proposed Methodologysystem"

The system works using keypad to enter a password to the system. If entered password is correct then door is open by motor which is used to rotate the handle of the door lock. System also includes extra features like adding new users and changing old password etc [1]. We surveyed many smart doors locking system. We found that these products are very expensive. Some of the implementation mentioned in the literature survey is very cost effective in implementation but do not provide multi user or multi level functionalities. We identified these requirements and thought to develop a system which is cost effective in implementation and having more advanced features like multi user and multilevel. These features are the need of time and such functionalities will make the system more useful. 


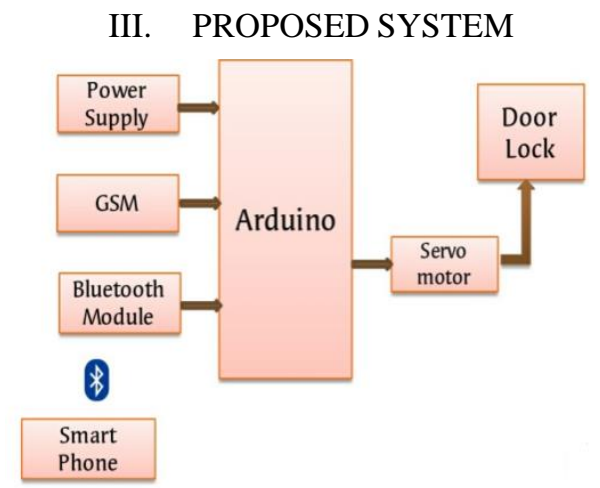

Fig.1. Proposed System

The main feature of the proposed system is its multi mode functionalities. The proposed system works on two6 different modes which are as follows: - .

\section{A. Normal Mode}

In this mode a single user can login and use the system. It has following features:-

- User can login using the registered password.

- User can lock or unlock the door with the password.

- Recovery of password is available if he/she forgets using the registered email address.

- User can reset the password if he feels it is not secure.

\section{B. Multiuser Mode}

This mode is useful when more than one users are authorized to operate lock. It has following features.

- Individual user can login using the registered password.

- Each individual user can login using his her own registered ID and password.

- Recovery of password is available if he/she forgets the password by using the e-mail provided earlier.

- Each Individual can reset the password if they feel it is not secure.

\section{Assumption}

Itis assumed that the users will operate the system using Android Smart Phones having Bluetooth features with the Bluetooth HC-05 which is been installed in the system. The mobile App which isdeveloped for Android Phones will not work on other platform. However it can be customized for other platform also. It is also assume that user will operate it within the Bluetooth device accessibility range of $10 \mathrm{~m}$ to $100 \mathrm{~m}$.

\section{SYSTEM IMPLEMENTATION}

The system is implemented using following hardware components:

\section{A. Arduino Uno Board}

It's actually the control board [Fig 2] which communicates with the Android Apps and triggers the door strike based on the command received from Android Apps.

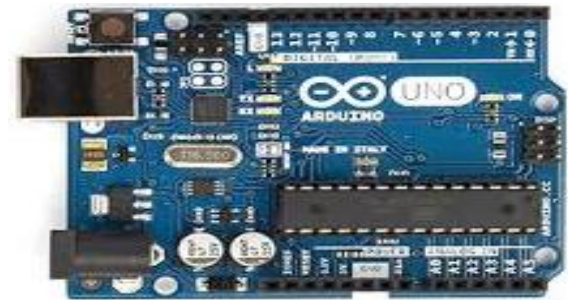

Fig. 2.Arduino Uno Board

\section{B. GSM Module}

SIM808 module is a complete Quad-Band GSM/GPRS module which combines GPS technology for satellite navigation. The compact design which is integrated GPRS and GPS in a SMT package will significantly save both time and cost for customers to develop GPS enabled applications. Featuring an industry-standard interface and GPS function, it allows variable assets to be tracked seamlessly at any location and atanytime with signal coverage.

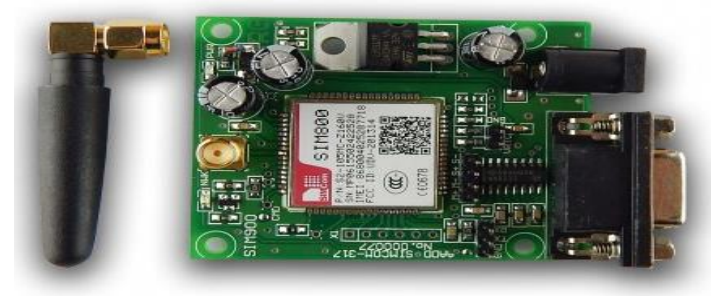

Fig. 3.GSM Module

\section{Electric Door Strike}

An electronic lock (or electric lock) is a locking device which operates by means of electric current [Fig 4].Electric Door Strike is used in this paper which willbe used as a locking device, which works based on the instruction fromArduino Uno Board.

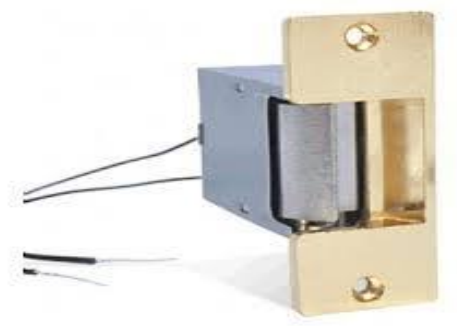

Fig. 4.Electric Door Strike

D. Bluetooth HC-05

HC-05 module is an easy to use Bluetooth SPP (Serial Port Protocol) module, designed for transparent wireless serial connection setup. This module is used to provide communication between Arduino Uno Board and the smart phone, which will have Android Apps to monitor the lock.
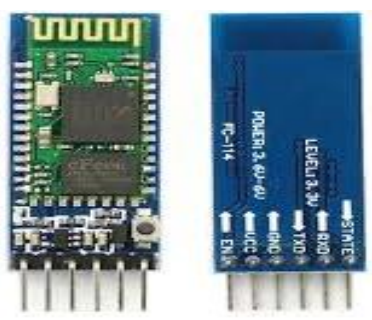

Fig. 5. Bluetooth HC-05 Module 
Table 1 shows the system components and its purposes.

\begin{tabular}{|c|l|}
\hline $\begin{array}{c}\text { Component } \\
\text { Name }\end{array}$ & \multicolumn{1}{|c|}{ Purpose } \\
\hline Arduinouno & $\begin{array}{l}\text { Receives the instruction from Android Apps and } \\
\text { process it. Based on the command, it controls the } \\
\text { Electric Door Strike. }\end{array}$ \\
\hline $\begin{array}{c}\text { Bluetooth } \\
\text { Module HC- } \\
05\end{array}$ & $\begin{array}{l}\text { Bluetooth Module is used for communication channel } \\
\text { between Arduino Uno and Mobile Phone. }\end{array}$ \\
\hline $\begin{array}{c}\text { Android } \\
\text { Smartphone }\end{array}$ & $\begin{array}{l}\text { It is used as User interface. User need to install } \\
\text { Android Apps which is developed to control the lock } \\
\text { and configuring the basic functionalities of the system. }\end{array}$ \\
\hline GSM SIM & $\begin{array}{l}\text { It is used for sending the message to the other users } \\
\text { after entering the door. }\end{array}$ \\
\hline
\end{tabular}

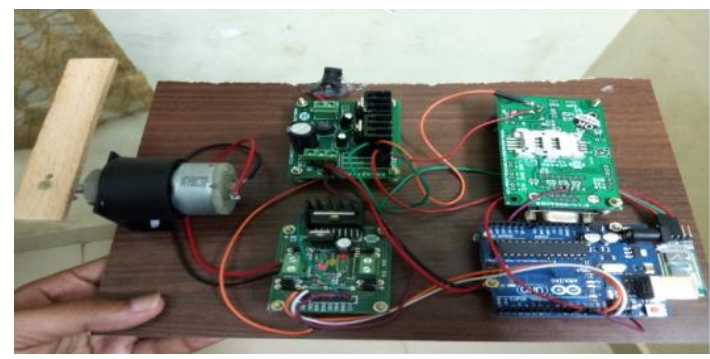

Fig. 6. System Representation

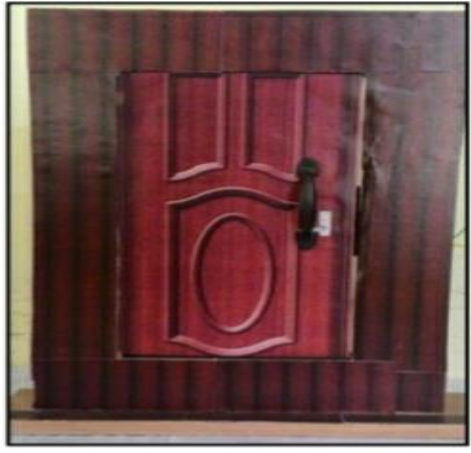

Fig 7:Shows The Demo Model Of Overall Implementation of the System

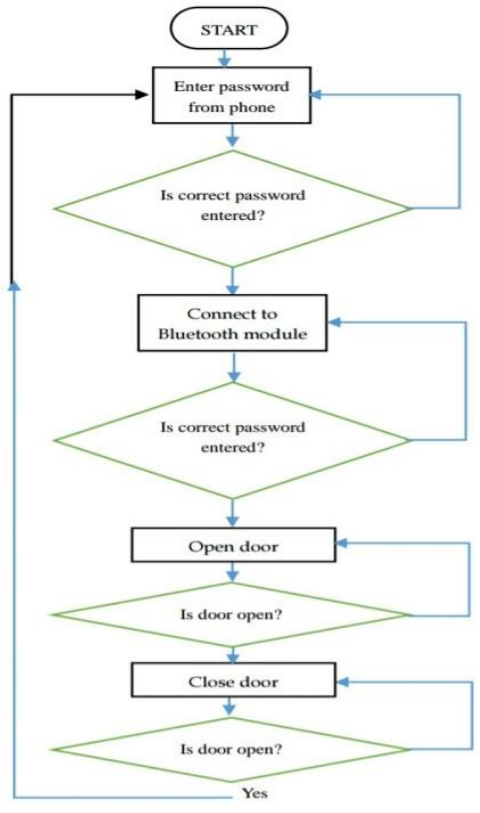

Fig. 8. Flowchart of Proposed Design

\section{CONCLUSION}

Thus "Android Based Smart Door Locking System" is a modern successor of the conventional door locking system.This system is very costeffective and easy to install and is designed under different modes which makes it useful.

\section{FUTURE SCOPE}

A rechargeable battery can be provided which can give power backup of 3-4hrs in case of power failure. It can also be implemented using cloud computing where user can control the lock irrespective of his location. Use of camera can also be done for surveillance. For further security, finger scanner, face recognizes oretc can be used. To avoid opening of door every time, voice conversation can also be done with the person on the other side of the door .This system can also be installed with a fire alarm. Usually at home we don't have fire alarms, so this system can work as both - lock and fire alarm. This system can be used in hotels, banks, motels, or any other place as an alternative lock for additional security.

\section{ACKNOWLEDGEMENT}

We would like to thank VVCE for sponsoring this project and giving the financial support. We would also like to thanks VVCE Management and my guides for their valuable suggestion, constant support and encouragement.

\section{REFERENCES}

[1] Arpita Mishra, Siddharth Sharma, SachinDubey, S.K.Dubey, "Password Based Security Lock System", International Journal of Advanced Technology in Engineering and Science, 2011.

[2] BhalekarPandurang, JamgaonkarDhanesh, Prof. Mrs. ShailajaPede, GhangaleAkshay, Garge Rahul, "Smart Lock: A Locking System Using Bluetooth Technology \& Camera Verification", International Journal of Technical Research, 2013.

[3] LiaKamelia, AlfinNoorhassan S.R, MadaSanjaya and W.S., Ed Mulyana , "Door-Automation System Using Bluetooth-Based Android For Mobile Phone", ARPN Journal of Engineering and Applied Sciences(ISSN 1819-6608), Vol. 9, No. 10, October 2014

[4] NeelamMajgaonkar, RuhinaHodekar, PriyankaBandagale, "Automatic Door Locking System", International Journal of Engineering Development and Research, Volume 4, Issue 1,2013 ISSN: 2321-9939.

[5] R.A. Ramlee, D. H. Z. Tang, M.M.Ismail, "Smart Home System for Disabled People Via Wireless Bluetooth", in Proc. of IEEE International Conference on System Engineering and Technology, pp. 1-4, 2012.

[6] Julius Bin Pelipos, "Smart Key Door with Wireless Security System using RF Signal," Faculty of Electrical and Electronic Engineering, UniversitiTun Hussein Onn Malaysia: Final Year Project Report, 2010.

[7] JunainaMohd Shah, "Door Locking System using RFID Technology," Faculty of Electrical and Electronic Engineering, UniversitiTun Hussein Onn Malaysia: Final Year Project Report, 2009.

[8] JulisahBintiMohamadIsah, "Main Door Security System using SMS." Faculty of Electrical and Electronic Engineering, UniversitiTun Hussein Onn Malaysia: Final Year Project Report, 2009.

[9] Harnani Hassan, Raudah Abu Bakar, Ahmad Thaqib and FawwazMokhtar, "Face Recognition Based on AutoSwitching Magnetic Door Lock System using Microcontroller" in International Conference on System Engineering and Technology, Indonesia, 2012.

[10] Stapathy, A. and Das, D.P., "A system for remote operation of devices: Helpful for elderly and disabled people" in Proc. of IEEE International Conf. on Advanced Electronic Systems, pp. 350353, 2013 
[11] Kuang-Yow Lian, Sung-Jung Hsiao and Wen-Tsai Sung, "Home Safety Handwriting Pattern Recognition System" in Proc. of IEEE 11th International Conf. on Cognitive Informatics and Cognitive Computing, pp. 477-483, 2012.

[12] R. D. H. Arifin and R. Sarno, "Door automation system based on speech command and pin using android smartphone," in 2018 International Conference on Information and Communications Technology (ICOIACT), March 2018, pp. 667-672.

[13] Y.W.Prakash,V.Biradar,S.Vincent,M.Martin,andA.Jadhav,"Smartbl uetoothlow energy security system," in 2017 International Conference on Wireless Communications, Signal Processing and Networking (WiSPNET), March 2017, pp. 2141-2146.

[14] M. Sahani, C. Nanda, A. K. Sahu, and B. Pattnaik, "Web-based online embedded door access control and home security system based on face recognition," in 2015 International Conference on Circuits, Power and Computing Technologies [ICCPCT2015], March 2015, pp. 1-6.

[15] R.S.Basyari,S.M.Nasution,andB.Dirgantara, "Implementationofhostc ardemulationmodeoverandroidsmartphoneasalternativeiso14443afor arduinonfcshield,"in 2015 International Conference on Control, Electronics, Renewable Energy and Communications (ICCEREC), Aug 2015, pp. 160-165. 